\title{
Primary Cutaneous Follicle Center Lymphoma
}

National Cancer Institute

\section{Source}

National Cancer Institute. Primary Cutaneous Follicle Center Lymphoma. NCI Thesaurus.

Code C7217.

A primary lymphoma of the skin composed of various numbers of small and large irregular neoplastic follicle center cells. Its morphologic pattern can be nodular, diffuse, or nodular and diffuse. It presents with solitary or grouped plaques and tumors, and it usually involves the scalp, forehead, or trunk. It rarely involves the legs. This type of cutaneous lymphoma tends to remain localized to the skin. 